\title{
Regulation of Cementoblast Gene Expression by Inorganic Phosphate In Vitro
}

\author{
B. L. Foster, ${ }^{1}$ F. H. Nociti Jr., ${ }^{1,2}$ E. C. Swanson, ${ }^{1}$ D. Matsa-Dunn, ${ }^{1}$ J. E. Berry, ${ }^{3}$ C. J. Cupp, ${ }^{4}$ P. Zhang, ${ }^{4}$ \\ M. J. Somerman' \\ ${ }^{1}$ Department of Periodontics, School of Dentistry, University of Washington, Seattle, WA, USA \\ ${ }^{2}$ Division of Periodontics, Department of Prosthodontics/Periodontics, School of Dentistry at Piracicaba, University of Campinas, \\ Piracicaba, Brazil \\ ${ }^{3}$ Department of Periodontics/Prevention/Geriatrics, School of Dentistry, University of Michigan, Ann Arbor, MI, USA \\ ${ }^{4}$ Nestlé Purina Research, St. Louis, MO, USA
}

Received: 1 September 2005 / Accepted: 18 October 2005 / Online publication: 6 February 2006

\begin{abstract}
Examination of mutant and knockout phenotypes with altered phosphate/pyrophosphate distribution has demonstrated that cementum, the mineralized tissue that sheathes the tooth root, is very sensitive to local levels of phosphate and pyrophosphate. The aim of this study was to examine the potential regulation of cementoblast cell behavior by inorganic phosphate $\left(\mathrm{P}_{\mathrm{i}}\right)$. Immortalized murine cementoblasts were treated with $\mathrm{P}_{\mathrm{i}}$ in vitro, and effects on gene expression (by quantitative real-time reverse-transcriptase polymerase chain reaction [RT-PCR]) and cell proliferation (by hemacytometer count) were observed. Dose-response $(0.1-10 \mathrm{mM})$ and time-course (1-48 hours) assays were performed, as well as studies including the Na-P $\mathrm{P}_{\mathrm{i}}$ uptake inhibitor phosphonoformic acid. Real-time RT-PCR indicated regulation by phosphate of several genes associated with differentiation/ mineralization. A dose of $5 \mathrm{mM} \mathrm{P} \mathrm{P}_{\mathrm{i}}$ upregulated genes including the SIBLING family genes osteopontin (Opn, $>300 \%$ of control) and dentin matrix protein-1 (Dmp-1, $>3,000 \%$ of control). Another SIBLING family member, bone sialoprotein $(B s p)$, was downregulated, as were osteocalcin $(\mathrm{Ocn})$ and type I collagen ( $\mathrm{Coll})$. Time-course experiments indicated that these genes responded within 6-24 hours. Time-course experiments also indicated rapid regulation (by 6 hours) of genes concerned with phosphate/pyrophosphate homeostasis, including the mouse progressive ankylosis gene (Ank), plasma cell membrane glycoprotein-1 ( $P c-1)$, tissue nonspecific alkaline phosphatase (Tnap), and the Pit 1 Na-P $\mathrm{P}_{\mathrm{i}}$ cotransporter. Phosphate effects on cementoblasts were further shown to be uptake-dependent and proliferation-independent. These data suggest regulation by phosphate of multiple genes in cementoblasts in vitro. During formation, phosphate and pyrophosphate may be important regulators of cementoblast functions including maturation and regulation of matrix mineralization.
\end{abstract}

Key words: Cementoblast - Phosphate - Pyrophosphate - Osteopontin - SIBLING gene

Correspondence to: B. L. Foster; E-mail: blfoster@u.wash ington.edu
Cementum is a mineralized tissue, similar in composition and properties to bone, that is synthesized by cementoblasts during tooth root formation and plays an essential role in anchoring the tooth to the surrounding alveolar bone. Examination of cementum development in ank/ ank mutant mice revealed cementoblasts to be exceptionally sensitive to extracellular inorganic pyrophosphate $\left(\mathrm{ePP}_{\mathrm{i}}\right)[1]$. The mouse progressive ankylosis protein (ANK) is a multipass transmembrane protein shown to regulate $\mathrm{PP}_{\mathrm{i}}$ transport from the cell interior to the extracellular milieu [2]. The ank/ank nonsense mutation therefore results in increased intracellular pyrophosphate $\left(\mathrm{iPP}_{\mathrm{i}}\right)$ and decreased $\mathrm{ePP}_{\mathrm{i}}$ as well as disruption in the overall ratio of available inorganic phosphate $\left(\mathrm{P}_{\mathrm{i}}\right)$ and $\mathrm{PP}_{\mathrm{i}}$. Mice carrying ank/ank have been used as a model for studying arthritis, and they present a phenotype including ectopic calcifications on articular surfaces and in synovial fluids, joint space narrowing, and osteophyte formation leading to fusion, joint immobility, and a characteristic flat-footed gait [2-4]. Upon studying the dentition, we found that ank/ank mutant mice also exhibited a $>10$-fold increase in cementum thickness, while maintaining apparently normal dimensions in the adjacent periodontal ligament (PDL) space, dentin, and alveolar bone. Another mouse model for $\mathrm{PP}_{\mathrm{i}}$ imbalance is the tiptoe walking ( $t t w$ or $E_{n p p^{-/}}$) mutant mouse carrying a mutation in the $P c-1$ gene that, like ank/ank, results in decreased ePP ${ }_{\mathrm{i}}$ [1]. The $t t w$ PC-1 mutant mouse exhibits hypermineralization abnormalities including ossification of the vertebral column and joints [5-7]. Interestingly, a tooth phenotype similar to that in ank/ ank was also observed in PC-1 mutant mice. While ANK and $\mathrm{PC}-1$ regulate accumulation of $\mathrm{ePP}_{\mathrm{i}}$, tissue nonspecific alkaline phosphatase (TNAP) catalyzes $\mathrm{PP}_{\mathrm{i}}$ breakdown to $P_{i}$. TNAP deficiency in humans and mice results in a condition of hypophosphatasia, marked by skeletal hypomineralization, skeletal abnormalities, and often a 
Table 1. Real-time PCR primer sequences

\begin{tabular}{llll}
\hline Gene & Accession & Forward $\left(5^{\prime}\right.$ to $\left.3^{\prime}\right)$ & Reverse $\left(5^{\prime}\right.$ to $\left.3^{\prime}\right)$ \\
\hline Bsp & L20232 & GAGACGGCGATAGTTCC & AGTGCCGCTAACTCAA \\
Opn & AF515708 & TTTACAGCCTGCACCC & CTAGCAGTGACGGTCT \\
Dmp -1 & NM 016779 & GCGCGGATAAGGATGA & GTCCCCGTGGCTACTC \\
Ocn & L24431 & TGAACAGACTCCGGCG & GATACCGTAGATGCGTTTG \\
Coll & NM 007743 & CACCCCAGCCGCAAAGAGT & CGGGCAGAAAGCACAGCACT \\
Ank & AF274752 & GAACTATCTGCCGCAC & AGGCGAGTAAACGCAA \\
$P c-1$ & AF339910 & CGCCACCGAGACTAAA & AGGAATCATAGCGTCCG \\
Tnap & AF285233 & GGGGACATGCAGTATGAGTT & GGCCTGGTAGTTGTTGTGAG \\
it 1 & AF172628 & ACCTGACCCCAATCAC & CCATGATAGCGGCACT \\
Gapdh & M32599 & ACCACAGTCCATGCCATCAC & TCCACCACCCTGTTGCTGTA \\
\hline
\end{tabular}

rickets-like condition [8-11]. TNAP deficiency also causes a dental phenotype distinguished by defective acellular cementum formation or no cementum at all, with the consequence of premature tooth loss [12,13]. Clearly, cementum formation is contingent on careful regulation of $\mathrm{PP}_{\mathrm{i}}$ and $\mathrm{P}_{\mathrm{i}}$ in the vicinity of the tooth root.

The aim of this study was to examine the role of $P_{i}$ and $\mathrm{PP}_{\mathrm{i}}$ in regulating genes associated with cementoblast activity and function. Though mechanisms of $\mathrm{P}_{\mathrm{i}} / \mathrm{PP}_{\mathrm{i}}$ regulation for particular genes are being investigated $[14,15]$, much remains to be explored, including the effects of phosphate on a broader range of genes and, more specifically, genes controlling behavior of cells within the tooth region. This is particularly of interest in light of the observation that in ank/ank mutant mice the cementum thickness dramatically increases, while surrounding alveolar bone and dentin tissues are apparently unchanged [1], suggesting different regulatory influences for cementum and adjacent mineralized tissues in response to this $\mathrm{PP}_{\mathrm{i}}$ imbalance.

\section{Materials and Methods}

\section{Cell Culture}

Immortalized murine cementoblasts (OCCM-30) were maintained in Dulbecco's modified Eagle medium (DMEM) supplemented with $10 \%(\mathrm{v} / \mathrm{v})$ fetal bovine serum (FBS) and penicillin, streptomycin, and $L$-glutamine $(100$ units $/ \mathrm{mL}$, $100 \mu \mathrm{g} / \mathrm{mL}$, and $2 \mathrm{mM}$, respectively; all tissue culture reagents from Invitrogen/GIBCO BRL, Carlsbad, CA). Cells were incubated at $37^{\circ} \mathrm{C}$ in an atmosphere of $5 \% \mathrm{CO}_{2}$. Isolation and characterization of OCCM-30 cementoblasts have been previously described [16] and were approved by the University Committee on Use and Care of Animals (University of Michigan, Ann Arbor, MI) and in compliance with state and federal laws.

\section{Cell Proliferation Experiments}

OCCM-30 cells were plated in $35 \mathrm{~mm}$ dishes at a concentration of $2 \times 10^{3} / \mathrm{cm}^{2}$ in DMEM with $10 \% \mathrm{FBS}$. One day after seeding, baseline cell counts were taken and media were changed to DMEM with 5\% FBS and treatment added. Phosphate was added at concentrations of 3, 5, and $7 \mathrm{mM}$, and media were changed every $2-3$ days during the course of the experiment. Cell counts were taken by hemacytometer at days 1,3 , and 6 after initial treatment.

\section{Gene Expression Experiments}

OCCM-30 cells were plated in $60 \mathrm{~mm}$ dishes at a concentration of $2.6 \times 10^{4}$ cells $/ \mathrm{cm}^{2}$ and maintained in DMEM with $10 \%$ FBS. Upon reaching confluence, media were changed to DMEM with 5\% FBS and experimental treatments were added. Total RNA was isolated by Trizol reagent (Invitrogen/ GIBCO BRL) 48 hours after initial addition of $P_{i}$. Phosphate was added to media at doses of $0.1-10.0 \mathrm{mM}$. Doses were based on our own observations as well as concentrations used by other researchers exploring the osteoblast response to $\mathrm{P}_{\mathrm{i}}$ $[17,18]$. A stock solution of $100 \mathrm{mM} \mathrm{P} \mathrm{P}_{\mathrm{i}}$ was made in DMEM at a $\mathrm{pH}$ of 7.4 and filter-sterilized.

For time-course experiments, cells were seeded and grown to confluence as described above. Following treatment with $5 \mathrm{mM} \mathrm{P}$, RNA was isolated at $1,6,24$, and 48 hours. To determine the requirement of $\mathrm{P}_{\mathrm{i}}$ entry into cells for cellular effects, media were supplemented with $3 \mathrm{mM}$ phosphonoformic acid (PFA, or foscarnet) in addition to $5 \mathrm{mM} \mathrm{P}_{\mathrm{i}}$ treatment for 24 hours. Total RNA was then harvested and analyzed as described above.

\section{Real-time Reverse-Transcriptase Polymerase Chain Reaction}

For real-time reverse-transcriptase polymerase chain reaction (RT-PCR) analysis, RNA was DNAse-treated (DNA-free ${ }^{\text {TM; }}$; Ambion, Austin, TX) and cDNA was synthesized from $1.0 \mu \mathrm{g}$ total RNA with a cDNA synthesis kit for RT-PCR (either First-Strand AMV or Transcriptor kit; Roche Diagnostic, Indianapolis, IN). Two microliters of the resulting cDNA product were used per $20 \mu \mathrm{L}$ reaction in the Lightcycler system (Roche Diagnostics, Mannheim, Germany). PCRs were carried out with the DNA Master SYBR Green I kit (Roche Diagnostic, Indianapolis, IN), with a total volume of $20 \mu \mathrm{L}$. Primers were designed by Lightcycler probe design software (Roche, Germany). A Basic Local Alignment Search Tool (BLAST) search of GenBank was performed on the primer sequences to ensure specificity, and melting curve analysis of products was additionally performed to ensure specificity. Expression was analyzed for genes including bone sialoprotein (Bsp), osteopontin $(O p n)$, dentin matrix protein-1 (DMP-1), osteocalcin $(\mathrm{Ocn})$, type I collagen (Coll), progressive ankylosis (Ank), plasma cell membrane glycoprotein-1 $(P c-1)$, thap, and Pit 1 type III sodium-dependent phosphate cotransporter (Pit1), with glyceraldehyde-3-phosphate dehydrogenase (Gapdh) serving as a housekeeping/reference gene for normalization. The amplification profile used on the Lightcycler was $95 / 0$, $55 / 7$, and $72 / 20$ (temperature $\left[{ }^{\circ} \mathrm{C}\right] /$ time [seconds]) and 35-40 cycles. Primer sequences are listed in Table 1 . All primers were used at a concentration of $0.5 \mu \mathrm{M}$ (except $D M P-1$, used at $0.25 \mu \mathrm{M}$ to optimize PCR conditions) in $3 \mathrm{mM} \mathrm{MgCl}_{2}$. 


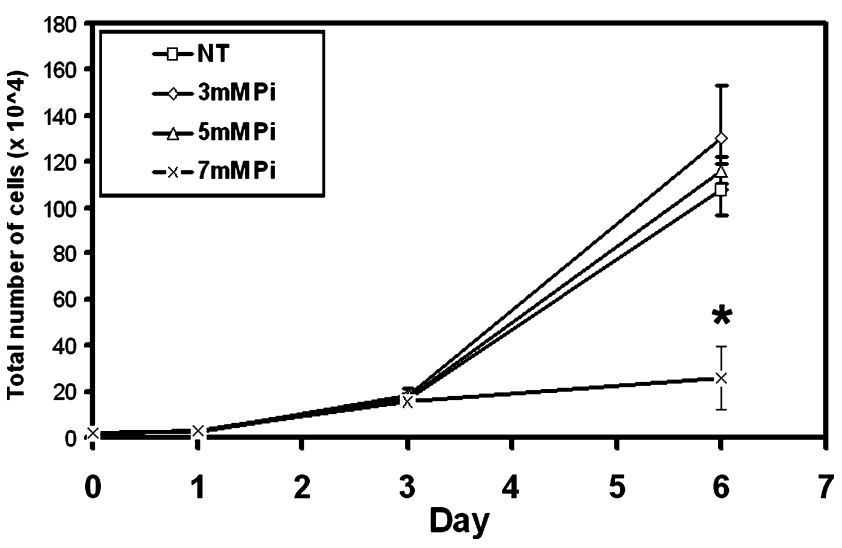

Fig. 1. Effect of phosphate on OCCM-30 cementoblast proliferation. Cementoblasts (OCCM-30) were plated in DMEM (10\% FBS) and 1 day after seeding (day 0 ) switched to $5 \%$ FBS DMEM with or without 3,5 , or $7 \mathrm{mM} \mathrm{P}_{\mathrm{i}}$. Total cell number per plate was determined by hemacytometer on days $0,1,3$, and 6; and average cell numbers per plate are represented on the graph \pm standard error. $* P<0.05$, treated vs. untreated control. Results from six experiments. $\square$ NT, no treatment, $\diamond$ $3 \mathrm{mM} \mathrm{Pi}, \triangle 5 \mathrm{mM} \mathrm{Pi}, \times 7 \mathrm{mM} \mathrm{Pi}$.

Relative quantification of PCR products was achieved by using LightCycler Relative Quantification Software, version 1.0 (Roche Diagnostics, Germany) to compare amplification of the target gene of interest to that of Gapdh as a reference gene, with calibrator normalization and amplification efficiency correction.

\section{Statistical Analysis}

Data from proliferation, dose-response, and PFA experiments were analyzed by analysis of variance (ANOVA) to determine differences among treatments, with further pairwise comparisons made by the Student-Newman-Keuls (SNK) test. $P \leq 0.05$ was used to indicate significance. Sigmastat 3.1 (Systat Software, Inc., Point Richmond, CA) was used for ANOVA statistical testing.

For analysis of the time-course experiment, PCR data from four independent experiments were transformed by calculating the log of the ratio of treated vs. untreated samples for a given time point. The transformation was performed in order to control for variation in passage-to-passage levels of basal expression in cells. Statistical significance of the $P_{i}$ treatment effect was assessed by applying a $t$-test to the log-transformed ratios $\left(\mathrm{P}_{\mathrm{i}} /\right.$ No treatment $)$ for each gene at each time point. $P \leq$ 0.05 was used to indicate significance. Excel (Microsoft, Redmond, WA) was used for statistical analysis of time-course experiments.

\section{Results}

Effect of Phosphate on OCCM-30 Cementoblast Proliferation

The effect of $\mathrm{P}_{\mathrm{i}}$ on cell proliferation was assessed to determine if changes in proliferation could be associated with the regulation of gene expression. OCCM-30 cells were treated with 3,5 , or $7 \mathrm{mM} \mathrm{P}$ (or untreated control) in DMEM plus 5\% FBS, and cells were counted by hemacytometer on days $0,1,3$, and 6 , where day 0 was the first day of treatment. Until day 3 , all treatments resulted in equivalent cell numbers. However, by day 6 , cells receiving the highest dose of $\mathrm{P}_{\mathrm{i}}(7 \mathrm{mM})$ exhibited decreased proliferation, while the $5 \mathrm{mM} \mathrm{P}_{\mathrm{i}}$-treated and untreated plates yielded the same numbers of cells. Cell numbers with the lowest dose of $3 \mathrm{mM} \mathrm{P} \mathrm{P}_{\mathrm{i}}$ were slightly higher at day 6 (Fig. 1).

\section{Effect of Phosphate on OCCM-30 Cementoblast Gene Expression: Dose Response}

$P_{i}$ treatment affected expression of genes associated with cementoblast differentiation and with mineral regulation (Bsp, Opn, Dmp-1, Ocn, and Coll). These genes were regulated in a dose-response fashion by $\mathrm{P}_{\mathrm{i}}$ treatments in the range of $0.1-10 \mathrm{mM}$ over the course of 48 hours. A dose of $5 \mathrm{mM} \mathrm{P} \mathrm{P}_{\mathrm{i}}$ was observed to be generally very effective at eliciting a cell response, while there were concerns that doses of 7 and $10 \mathrm{mM}$ may have created stressful conditions for cells (see proliferation experiment results, Fig. 1). The highest two doses were not used in subsequent time-course experiments. Among the small integrin-binding ligand, N-linked glycoprotein (SIBLING) family genes, considerable increases were observed in Opn ( $>300 \%$ of control) and Dmp-1 ( $>3,000 \%$ of control) with $5 \mathrm{mM} \mathrm{P} \mathrm{P}_{\mathrm{i}}$, while $B s p$ expression was downregulated by about $25 \%$. To the authors' knowledge, this is the first report of in vitro expression of Dmp- 1 by cementoblasts. SIBLING member dentin sialophosphoprotein ( $D s p p$ ) expression was also observed in cementoblasts, with indications of a similar upregulation of $D s p p$ by $\mathrm{P}_{\mathrm{i}}$; however, overall $D s p p$ expression was extremely low in these cells, and results were somewhat variable (data not shown). Other genes important in matrix synthesis and regulation of mineralization were downregulated, with $O c n$ substantially declining by about $85 \%$ and Coll being affected with a decrease of about $50 \%$ (Fig. 2).

\section{Effect of Phosphate on OCCM-30 Cementoblast Gene Expression: Time Course}

Having established that several genes associated with cementoblast differentiation/mineralization were regulated by $\mathrm{P}_{\mathrm{i}}$, the next step was to determine the time required to realize these regulatory effects. A dose of $5 \mathrm{mM} \mathrm{P} \mathrm{P}_{\mathrm{i}}$ was chosen for these experiments because this dose delivered a robust response for the genes of interest but did not seem be associated with the potentially stressful conditions of higher $\mathrm{P}_{\mathrm{i}}$ doses. Time-course experiments indicated that these genes responded relatively quickly to phosphate regulation, within 6-24 hours (Fig. 3). Patterns of expression varied from gene to gene, as has been previously described for OCCM-30 cells (and osteoblasts), with variations in expression over time in untreated samples as well.

Time-course experiments also indicated rapid regulation (by 6 hours) of genes concerned with $\mathrm{P}_{\mathrm{i}} / \mathrm{PP}_{\mathrm{i}}$ handling and homeostasis, including the mouse Ank gene, $P c-1$, 

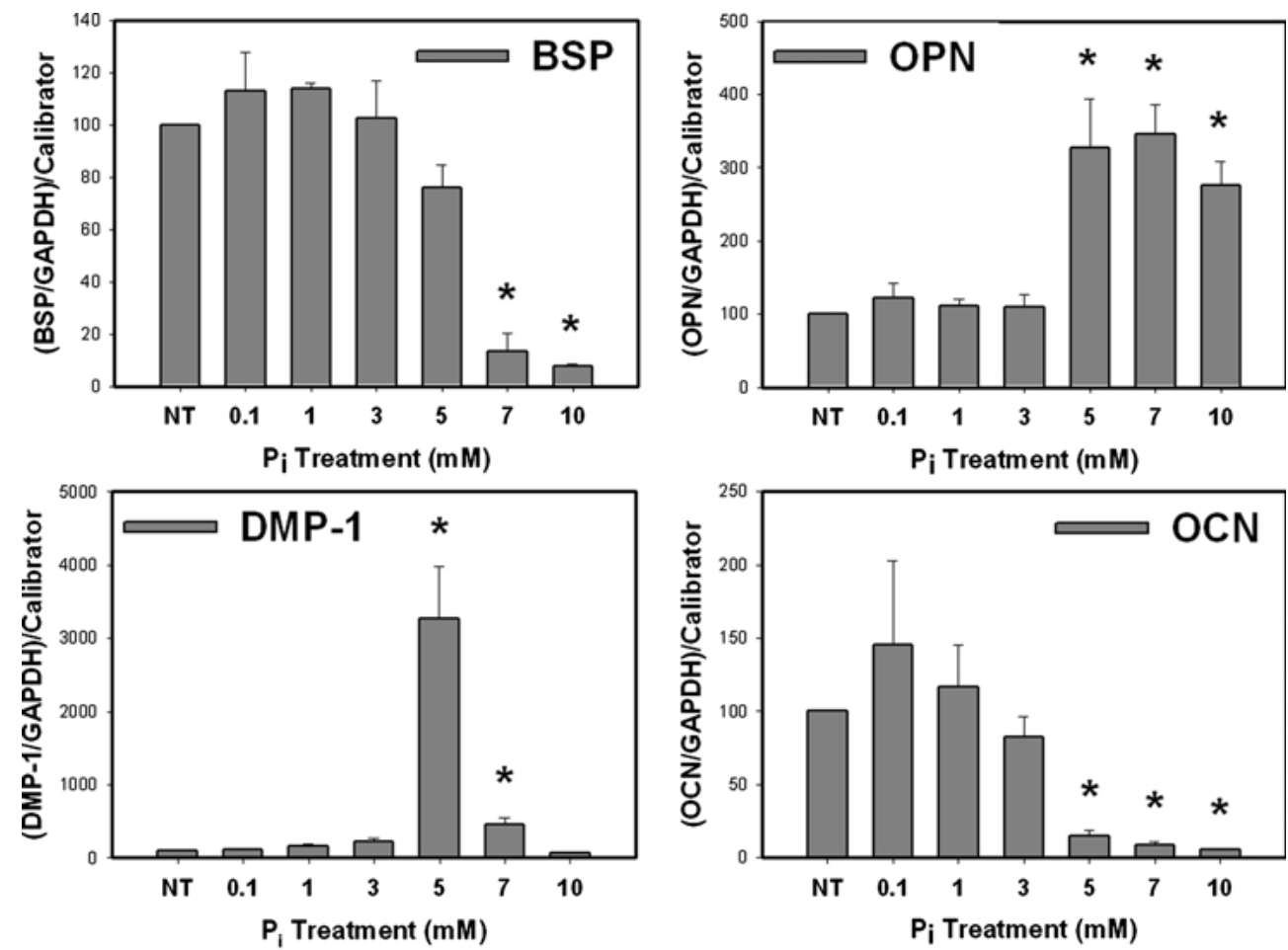

Fig. 2. Effect of phosphate on OCCM-30 cementoblast gene expression: dose response. Confluent cementoblasts (OCCM-30) were cultured in DMEM $(5 \%$ FBS $)$ plus $P_{i}$ at doses of $0.1-10 \mathrm{mM}$ for 48 hours. Total RNA was extracted and used to synthesize cDNA, and quantitative real-time PCR was used to check expression of differentiation- and mineralization-related genes, including Bsp, Opn, Dmp-1, Ocn, and Coll. Results were normalized to $G A P D H$ as a reference gene and calibrator sample. Results are presented as percent of untreated control (NT) on the $y$ axis, with standard error indicated by error bars. ${ }^{*} P<0.05$, treated vs. untreated control. Results from three experiments.

Tnap, and Pit1 (Fig. 3). Strong upregulation was observed in Ank (300\% of control), PC-1 (700\% of control), and Pit1 (200\% of control), while Tnap expression greatly decreased (ultimately by $85 \%$ ). OCCM-30 cementoblasts are differentiated cells that do not require ascorbic acid (AA) for induction of differentiation/mineralization genes, as do some precursor cells such as the murine osteoprogenitor cells MC3T3-E1 [19]. Nonetheless, experiments with added AA $(50 \mu \mathrm{g} / \mathrm{mL})$ were performed; and while some basal gene expression was higher with AA (as has been previously observed), response to $\mathrm{P}_{\mathrm{i}}$ for all genes analyzed followed the same trend with or without AA (data not shown).

\section{Effect of Phosphate Transport Inhibition on OCCM-30 Cementoblast Gene Expression}

In order to determine whether the observed effects on gene expression were $\mathrm{P}_{\mathrm{i}}$-specific, entry of $\mathrm{P}_{\mathrm{i}}$ into cells was blocked by treatment with the competitive inhibitor of Na- $\mathrm{P}_{i}$ transport PFA, also called foscarnet. With addition of $3 \mathrm{mM}$ PFA concurrent with $\mathrm{P}_{\mathrm{i}}$ exposure for 24 hours, gene regulation by $P_{i}$ was substantially diminished (Opn and Dmp-1 shown here), indicating that $\mathrm{P}_{\mathrm{i}}$ uptake is indeed necessary to realize these transcriptional changes. While induction of gene expression by $\mathrm{P}_{\mathrm{i}}$ was not completely abolished, there was a considerable dampening of response by blocking $P_{i}$ uptake. PFA addition did not affect basal cell expression, as indicated by unaltered Gapdh levels between PFA-treated and untreated samples (data not shown) (Fig. 4).

\section{Discussion}

Our results support cell regulatory properties of $\mathrm{P}_{\mathrm{i}}$, as reported by other groups using other cell types. We now report additional effects of $\mathrm{P}_{\mathrm{i}}$ on cementoblast cell behavior and indicate that the changes in genes associated with the mature cementoblast may be unique to this 

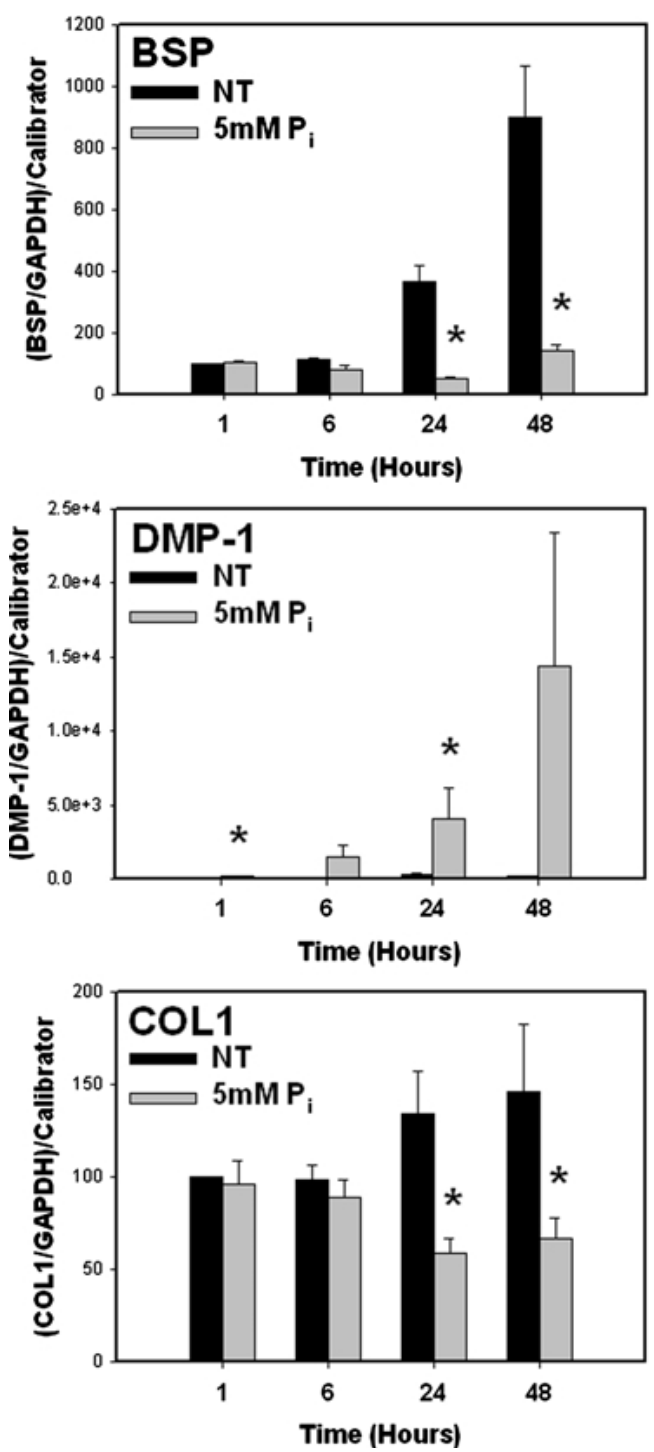
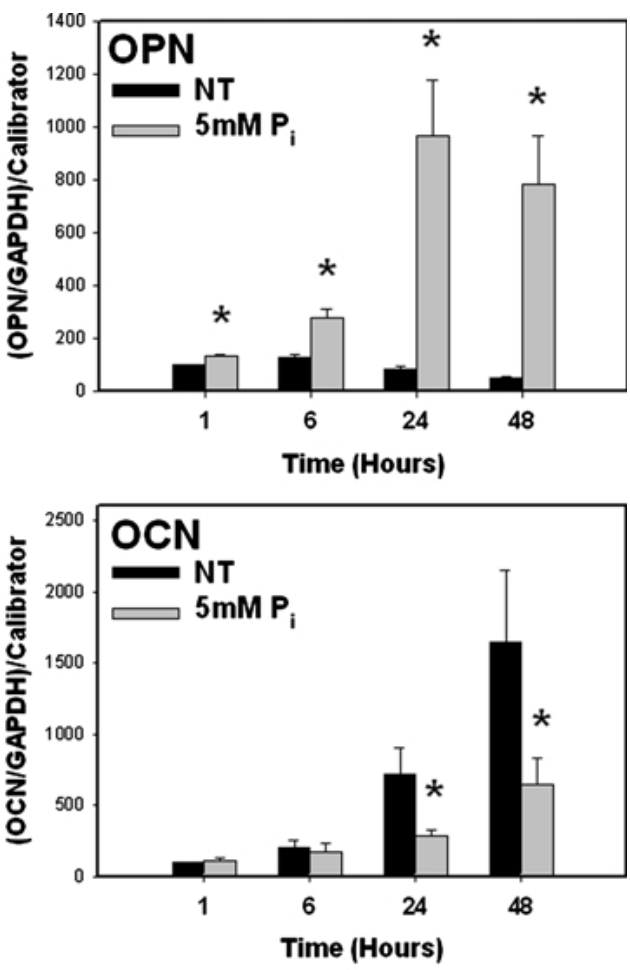

Fig. 3. Effect of phosphate on OCCM-30 cementoblast gene expression: time course. Cementoblasts (OCCM-30) were plated and cultured as described in the dose-response experiments (above), with a $\mathrm{P}_{\mathrm{i}}$ dose of $5 \mathrm{mM}$. Total RNA was extracted at 1, 6, 24, and 48 hours and used to synthesize cDNA; quantitative real-time PCR was used to check gene expression. Treated samples are indicated by $\mathrm{P}_{\mathrm{i}}$ and untreated controls by NT. Expression levels analyzed included genes for differentiation and mineralization and $\mathrm{P}_{\mathrm{i}} / \mathrm{PP}_{\mathrm{i}}$ homeostasis. Results are presented as percent of untreated control, where control is NT at 1 hour, with standard error indicated by error bars. ${ }^{*} P<0.05$ difference of log-transformed $\mathrm{P}_{\mathrm{i}}$-treated vs. NT control data from same time point. Results from four experiments. cell phenotype. Opn, Dmp-1, Ank, Pc-1, and Pit1 mRNA levels were increased, while Bsp, Ocn, Coll, and Tnap mRNA levels were decreased (Figs. 2 and 3). Most of these genes responded within 6 hours, suggesting a relatively rapid response to $\mathrm{P}_{i}$ treatment (Fig. 3). Importantly, it was shown that $\mathrm{P}_{\mathrm{i}}$ must enter the cell to cause the observed changes in gene expression (Fig. 4). No effects of 3 or $5 \mathrm{mM} \mathrm{P}_{\mathrm{i}}$ on proliferation were observed, though $7 \mathrm{mM} \mathrm{P}_{\mathrm{i}}$ at day 6 notably decreased proliferative potential (Fig. 1).

\section{Phosphate Regulates Differentiation/Mineralization Genes}

The genes regulated by $P_{i}$ in cementoblasts could be split into at least two "functional" groups: (1) positive/negative regulators of differentiation/mineralization, and (2) phosphate/pyrophosphate homeostasis genes. In the first group, notably, several members of the SIBLING family were regulated by $\mathrm{P}_{\mathrm{i}}$ in cementoblasts, including $O p n$ and
Dmp- 1 (both increased) and Bsp (decreased) (Figs. 2 and 3A). The SIBLING family is comprised of genes encoding extracellular matrix proteins from mineralized tissues that are located on human chromosome 4 (mouse chromosome 5) and have in common the presence of an arginine-glycine-aspartate (RGD) integrin binding domain, exon organizational features, and similarity in posttranslational modifications, including glycosylation and phosphorylation [20-22]. In addition to functioning as extracellular matrix proteins involved in the regulation of hydroxyapatite mineral initiation and growth, SIBLING members have been implicated in cell attachment, local activation of matrix metalloproteinases, extracellular matrix maturation, wound healing, and protection of cells from alternative complement pathway lysis, among other functions [23-25].

SIBLING family transcripts Bsp, Opn, and Dmp-1 were shown to be regulated by $\mathrm{P}_{\mathrm{i}}$ in these studies. $D s p p$ expression was also detected in OCCM-30 cemento- 

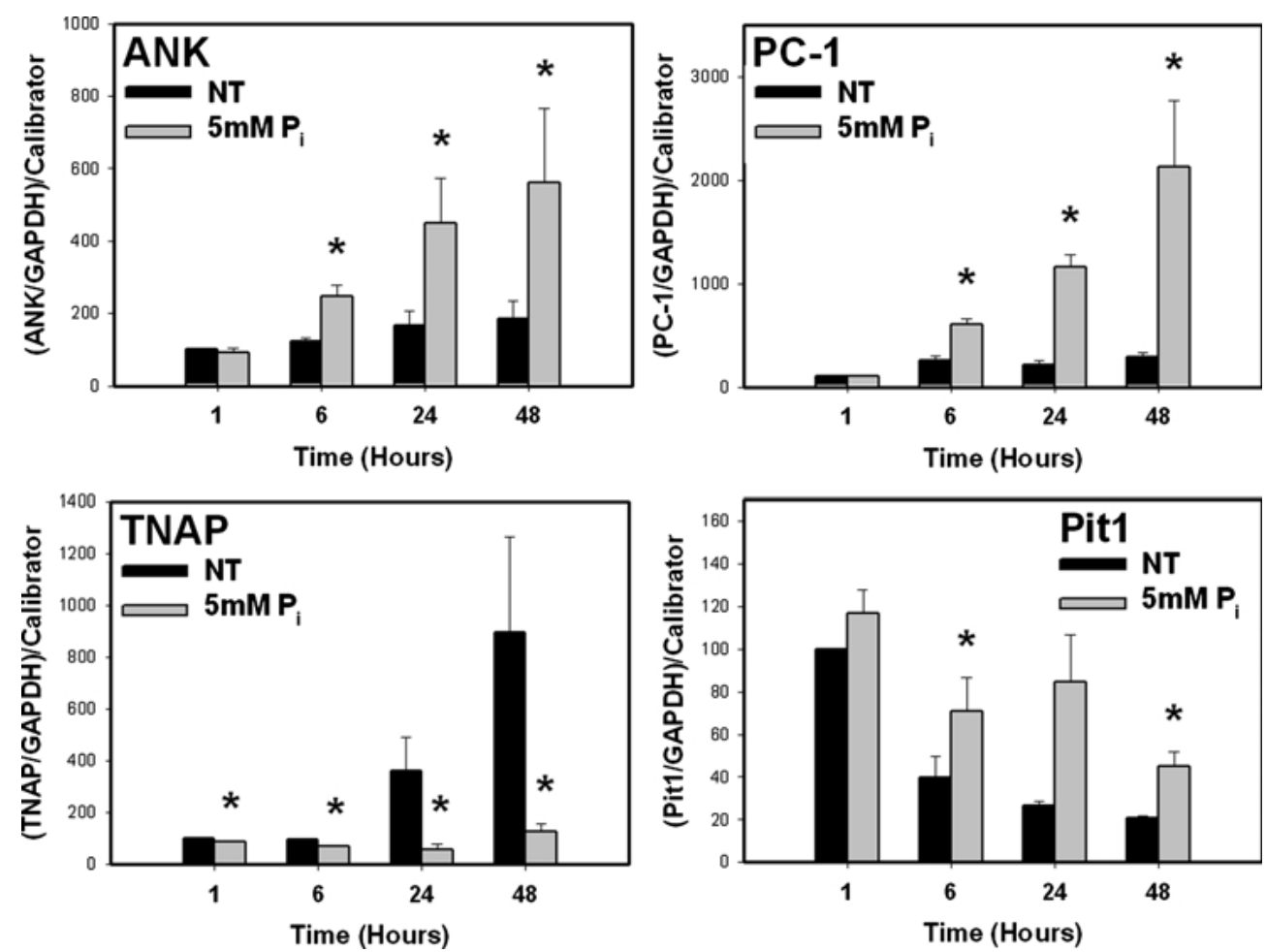

Fig. 3. Continued.

blasts, and there was some evidence of $\mathrm{P}_{\mathrm{i}}$ regulation of this SIBLING member; however, expression was extremely low, leading to variable results (data not shown). OPN, in its phosphorylated form, is a potent inhibitor of hydroxyapatite crystal growth [26]; conversely, many studies support roles for BSP and DMP-1 as nucleators/promoters of mineral formation [27, 28]. There is evidence that DSPP cleavage products DSP and DPP, as well as DMP-1, are important in controlling dentin formation as they are expressed during dentinogenesis [29] and DMP-1-deficient mice exhibit reduced and hypomineralized dentin $[30,31]$. Currently, a role for these genes/proteins in cementogenesis has not been established. Thus, future studies into the roles of DSP, DPP, and DMP-1 in cementogenesis should be considered. A recent study by Takano et al. [32] showed a potential effect of DSP on cellular cementum formation in rats and guinea pigs, and we now report in vitro cementoblast expression of SIBLING members Dmp-1 and Dspp. The modulation of SIBLING expression, while striking, seems in sum to be a mixed signal with regard to differentiation and mineralization.

\section{Phosphate Regulates $P_{i} / P P_{i}$ Homeostasis Genes}

Phosphate homeostasis genes in OCCM-30 cementoblasts were shown to respond to $\mathrm{P}_{\mathrm{i}}$ regulation. Ank and $P c-1$, which increase $\mathrm{PP}_{\mathrm{i}}$ in the extracellular environment through different processes, are both strongly upregulated in response to increased $\mathrm{P}_{\mathrm{i}}$ (Fig. 3). Thap, one of the primary enzymes in mineralized tissues for liber- ation of $\mathrm{P}_{\mathrm{i}}$ from $\mathrm{PP}_{\mathrm{i}}$, was convincingly downregulated (Fig. 3), possibly part of a negative feedback mechanism. Terkeltaub's group [33] observed that $P c-1$ expression was decreased in Tnap $^{-/-}$mice and showed in MC3T3-E1 and calvarial osteoblasts that increased TNAP enzyme activity significantly increased PC-1 function; here, we show that the mechanism was likely via $\mathrm{P}_{\mathrm{i}}$, by observing the same reciprocal relationship between Tnap and $P c-1$ on the mRNA level. Additionally, we show that Ank is regulated by $\mathrm{P}_{\mathrm{i}}$ in a manner comparable to $P c-1$. Similarly, in ank/ank and $t t w / t t w$ mutant mice, in which mutated ANK and PC-1 proteins decrease $e \mathrm{PP}_{\mathrm{i}}$, OPN is also reported to be substantially decreased [34]. TNAP function is normal in these animals, so decreased ePP may also mean decreased $P_{i}$ (because through the action of TNAP, $\mathrm{PP}_{\mathrm{i}}$ becomes a pool available for creation of $\mathrm{P}_{\mathrm{i}}$ ) and, subsequently, low OPN expression.

In addition to changes in Ank, $P c-1$, and Tnap, the type III sodium-dependent phosphate transporter Pit1 was upregulated by addition of $\mathrm{P}_{\mathrm{i}}$ (Fig. 3B). Pitl is highly expressed in MC3T3-E1 preosteoblast cells, and its expression increased during differentiation, suggesting a role in osteoblast calcification of the extracellular matrix [35]. Additionally, we here show Pit1 expression in cementoblasts and further demonstrate upregulation in response to $\mathrm{P}_{\mathrm{i}}$, likely facilitating $\mathrm{P}_{\mathrm{i}}$ uptake to the cell interior, where regulation of other genes may be the result. When $P_{i}$ uptake into cells is blocked, as with inclusion of the $P_{i}$ transport inhibitor foscarnet, gene regulation by $P_{i}$ is substantially diminished (Fig. 4). 


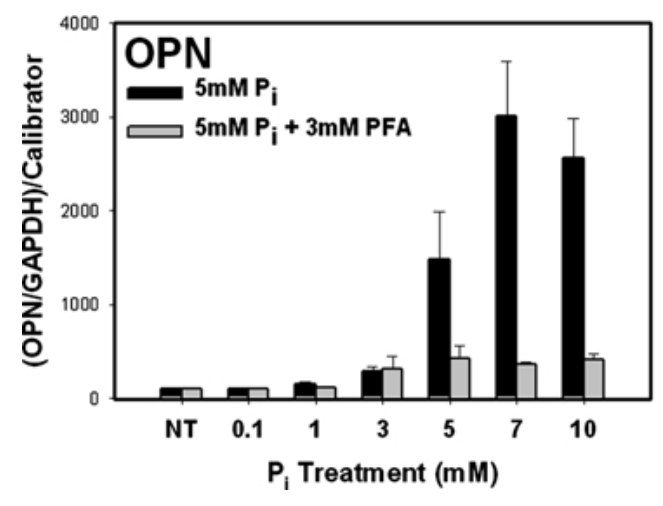

Fig. 4. Effect of phosphate transport inhibition on OCCM-30 cementoblast gene expression. Cementoblasts (OCCM-30) were plated as described in the dose-response experiment (above). Prior to addition of $\mathrm{P}_{\mathrm{i}}$ treatment $(0.1-10 \mathrm{mM})$ at time 0 hours, cells were pretreated for 30 min with $3 \mathrm{mM}$ PFA, also known as foscarnet, an inhibitor of $\mathrm{Na}-\mathrm{P}_{\mathrm{i}}$ transport into the cell. $\mathrm{P}_{\mathrm{i}}$ doses and PFA remained in the culture media until total

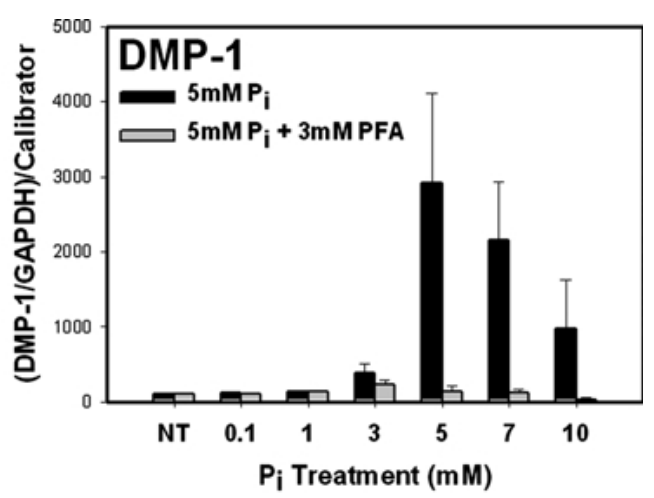

RNA was isolated 24 hours after treatment and used to synthesize cDNA and perform quantitative real-time PCR. Shown here are effects of PFA treatment on expression of the SIBLING family genes $O p n$ and $D m p-1$ vs. untreated controls (NT). Results are presented as percent of untreated control on the $y$ axis, with standard error indicated by error bars. Results from three experiments.

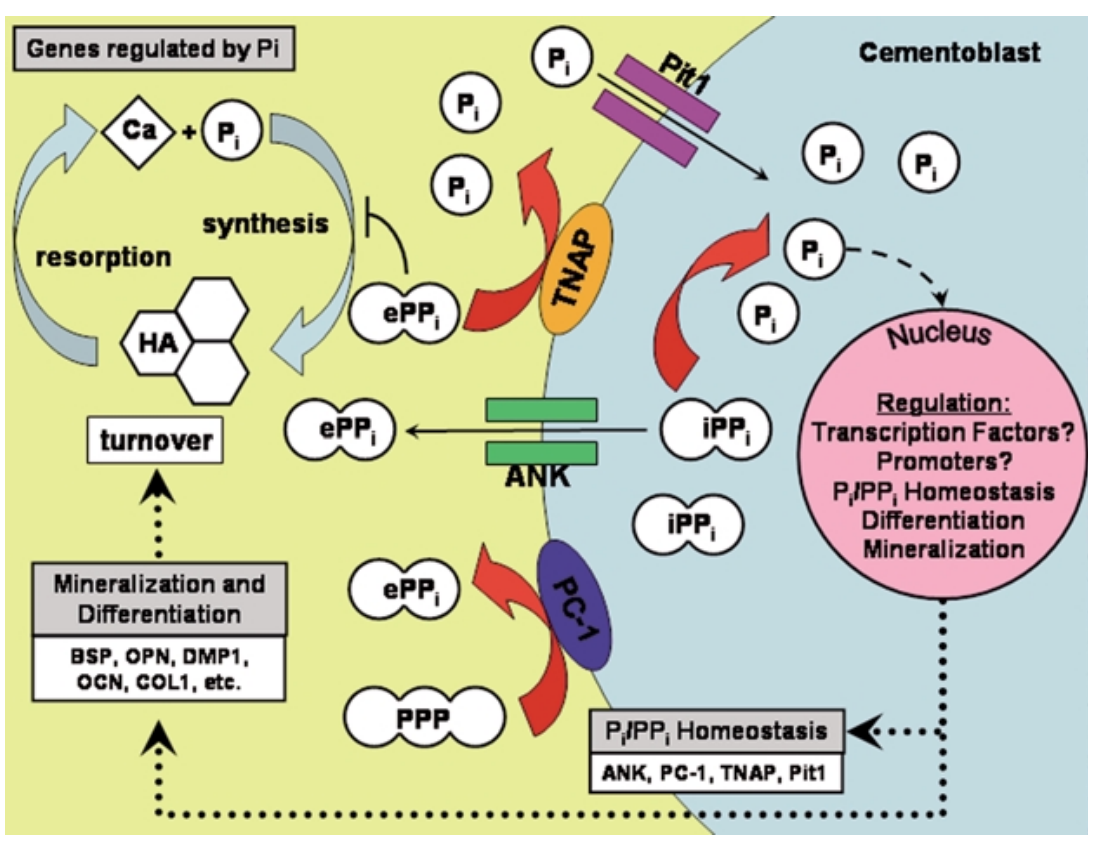

Fig. 5. Model for the regulation of cementoblast cell behavior by $\mathrm{P}_{\mathrm{i}} . \mathrm{P}_{\mathrm{i}}$ and calcium $(\mathrm{Ca})$ are the building blocks for hydroxyapatite (HA) mineral in the body and released during mineral tissue turnover. $\mathrm{ePP}_{\mathrm{i}}$ is a potent inhibitor of HA formation. Several proteins regulate the local concentrations of $\mathrm{Pi}$ and $\mathrm{PPi}$, including the Pit1 Na- $P_{i}$ cotransporter TNAP that catalyzes conversion of $\mathrm{PP}_{\mathrm{i}}$ to $\mathrm{P}_{\mathrm{i}}$, the progressive ankylosis protein that regulates $\mathrm{PP}_{\mathrm{i}}$ transfer from the intracellular space $\left(\mathrm{iPP}_{\mathrm{i}}\right)$ to the extracellular $\left(\mathrm{ePP}_{\mathrm{i}}\right)$ milieu, and $\mathrm{PC}-1$ plasma cell membrane glycoprotein that catalyzes $\mathrm{PP}_{\mathrm{i}}$ production from triphosphates (PPP). Here, we show that $\mathrm{P}_{\mathrm{i}}$ addition can regulate genes involved in $\mathrm{P}_{\mathrm{i}} / \mathrm{PP}_{\mathrm{i}}$ homeostasis (Pit1, TnapP, Ank, Pc-1) and those known to be important in the maturation and mineralizing functions of cementoblasts and other mineralizing cells (Bsp, Opn, Dmp-1, Ocn, Coll).

\section{Regulation of $P_{i} / P P_{i}$ by Cementoblasts}

The sum result of the changes in ANK, PC-1, and TNAP would be increased $e \mathrm{PP}_{\mathrm{i}}$, perhaps an attempt to compensate for the $\mathrm{P}_{\mathrm{i}}$ excess and return the $\mathrm{P}_{\mathrm{i}} / \mathrm{PP}_{\mathrm{i}}$ ratio back to the balance of homeostasis. We hypothesize that in addition to absolute levels of $\mathrm{P}_{\mathrm{i}}$ and $\mathrm{PP}_{\mathrm{i}}$ available in the extracellular pool, the relative ratio of $\mathrm{P}_{\mathrm{i}} / \mathrm{PP}_{\mathrm{i}}$ may be important. When exposed to excess $\mathrm{P}_{\mathrm{i}}$, the cellular response is to compensate with greater $\mathrm{ePP}_{\mathrm{i}}$ through increased PC-1 and ANK and decreased TNAP. The cell may also compensate through modulating $P_{i}$ levels, such as by increased $P_{i}$ uptake via Pit1. After one mechanism compensates, levels of $\mathrm{P}_{\mathrm{i}}$ and $\mathrm{PP}_{\mathrm{i}}$ may approach normal over time, and gene expression may again relax to a constitutive level. In this way, the tightly regulated and dynamic antagonism of $\mathrm{P}_{\mathrm{i}}$ vs. $\mathrm{PP}_{\mathrm{i}}$ continues. Indeed, Millan's group [7] showed that by crossing Tnap knockout (Akp2) and Pc-1 knockout (Enpp1) mice, in vitro and in vivo mineralizing capabilities of osteoblasts were returned to normal and $\mathrm{ePP}_{\mathrm{i}}$ levels in the double knockout were comparable to wild type, possibly with the facilitation of ANK or other factors. The cementum from these animals is currently under examination. The importance of the $\mathrm{P}_{\mathrm{i}} / \mathrm{PP}_{\mathrm{i}}$ ratio in both mineralized tissue and pathological calcifications is explored in depth in a series of well-conceived experiments by Murshed et al. [36], highlighting the working rela- 
tionships between ANK, PC-1, and TNAP, as well as other proteins involved in $\mathrm{P}_{\mathrm{i}}$ metabolism and regulation of mineralization.

\section{Role of Cementoblasts}

The reaction by cementoblasts to excess $P_{i}$ is to decrease transcripts for the differentiation genes $B s p$ and $O c n$ while increasing the hydroxyapatite inhibitor $O p n$ and potentially increasing $\mathrm{ePP}_{\mathrm{i}}$ via $A n k, P c-1$, and Tnap regulation. In total, these results may be an indication that mature cementoblasts, once their role in cementum formation has been fulfilled, promote periodontal homeostasis by self-regulating their mineralization capacity, even when conditions (such as high $\mathrm{P}_{\mathrm{i}}$ ) favor hydroxyapatite formation. A similar response has been evoked by treating this same cementoblast cell line with the differentiation factor BMP-2, causing these mature cells to downregulate $B s p$ and $O c n$ and reduce in vitro mineral nodule formation [37]. Additionally, when treated with a bisphosphonate (specifically, etidronate), which alters proliferation, differentiation, and gene expression in osteoblasts [38, 39], these cementoblasts responded with downregulation of $C b f a l$ and $O c n$ and upregulation of $O p n$, further indicating a responsive but reactive metabolism relative to nearby osteoblasts [40].

These results with cementoblasts in vitro alone do not explain in vivo observations of a hypercementosis phenotype in ank/ank and $t t w / t t w$ mutant mice. $\mathrm{ePP}_{\mathrm{i}}$ is decreased as a result of both of these mutations, so the ratio of $\mathrm{P}_{\mathrm{i}} / \mathrm{PP}_{\mathrm{i}}$ may increase, favoring hydroxyapatite formation rather than suppression. When treated with $P_{i}$ in vitro, cementoblasts responded by regulating transcripts in a way that would decrease or deemphasize mineralization and increase $\mathrm{ePP}_{\mathrm{i}}$. Cementoblast behavior in vivo is probably more complex than previously thought, reflecting interactions with other cells and signaling molecules during development.

\section{Phosphate as a Signaling Molecule}

Phosphate present in the extracellular milieu of mineralizing cells (cementoblasts, osteoblasts, odontoblasts, etc.) may serve as a signal for a shift in cell function/ differentiation, in addition to acting as one of the building blocks for hydroxyapatite mineral. Studies by several groups have begun to explore the mechanisms of $\mathrm{P}_{\mathrm{i}}$ and $\mathrm{PP}_{\mathrm{i}}$ regulation of cell gene expression (for a thorough review of $\mathrm{PP}_{\mathrm{i}}$ pathophysiology, see [41]). $\mathrm{P}_{\mathrm{i}}$ was first shown to be a direct inducer of $O p n$ expression in MC3T3-E1 preosteoblast cells [42] and hypothesized to act as a signal to cue these precursor cells to undergo cellular changes necessary for differentiation and matrix mineralization $[14,18,43]$. The OCCM-30 cementoblasts used in the present study, however, are more differentiated cells and not necessarily primed to re- spond in the same way to molecular signals from an earlier developmental stage. In fact, these mature cells have been shown to downregulate differentiation- and mineralization-associated gene transcripts such as $B s p$ and $O c n$ when exposed to prodifferentiation signals such as $B M P-2$ [37], while the putative precursor dental follicle cell can be induced to differentiate to a mineralizing phenotype by BMP-2 [44]. Therefore, if mature cementoblasts respond to a $P_{i}$ signal, it may not be a shift toward differentiation and need not be interpreted as such.

$\mathrm{P}_{\mathrm{i}}$ has additionally been shown to be an apoptogen for chondrocytes and osteoblasts in the $1-10 \mathrm{mM}$ range, possibly a signal for the clearing of terminally differentiated cells, with osteoblasts showing relatively less sensitivity to $\mathrm{P}_{\mathrm{i}}$ treatment than tibial chondrocytes $[17,45]$. This histological clearing would accomplish the removal of cells that had served their purpose (e.g., chondrocytes in the tibial growth plate) or that needed to be removed for tissue remodeling (osteoblasts or osteocytes during bone turnover). While cementoblasts have been found to be phenotypically very similar to osteoblasts [46, 47] and cementum is similar to both bone and dentin in composition (all are carbonated hydroxyapatite), cementum is not known to undergo significant remodeling during its lifetime. In fact, cementum seems to be extremely resistant to resorption by osteo-/odontoclasts, as evidenced by the relative rarity of cementum resorption and its resistance to resorption even when adjacent alveolar bone is being actively resorbed, as in conditions of advanced periodontal disease. Cementoblasts may play a protective role against root resorption, and we have shown a high production of osteo-protegerin $(\mathrm{Opg})$ in cementoblasts in vitro, suggesting that this role may include active production of antiresorptive factors [48, 49]. Therefore, cementoblasts may not respond to such cues for apoptosis and may be less sensitive (than chondrocytes and osteoblasts) or not sensitive to $\mathrm{P}_{\mathrm{i}}$ as an apoptosis signal. Other possible roles for $\mathrm{P}_{\mathrm{i}}$ include those proposed by George's group [50] and Shapiro's group [51, 52], which further implicate a potential role for $\mathrm{Ca}^{2+}$ ions in conjunction with $\mathrm{P}_{\mathrm{i}}$-mediated signaling events, a facet that we did not examine here.

\section{Phosphate and the Cementoblast}

What emerges is a portrait of the cementoblast as a sophisticated cell operating in a complex environment and $\mathrm{P}_{\mathrm{i}}$ as a multitasking ion operating in mineralized tissue formation (Fig. 5). Along with calcium, $\mathrm{P}_{\mathrm{i}}$ is a necessary building block for hydroxyapatite formation that is released during mineral tissue turnover. While $e P P_{i}$ is a potent inhibitor of hydroxyapatite formation, it is also present as a pool for $P_{i}$ creation via the action of enzymes such as TNAP. In this way, several proteins 
regulate local concentrations of $\mathrm{P}_{\mathrm{i}}$ and $\mathrm{PP}_{\mathrm{i}}$, increasing, decreasing, and transporting $\mathrm{P}_{\mathrm{i}}$ and $\mathrm{PP}_{\mathrm{i}}$. Here, we show that $\mathrm{P}_{i}$ regulates genes involved in $\mathrm{P}_{i} / \mathrm{PP}_{\mathrm{i}}$ homeostasis and those known to be important in the maturation and mineralizing functions of cementoblasts and other mineralizing cells, such as SIBLING family genes. During formation, $\mathrm{P}_{\mathrm{i}}$ may be an important regulator of cementoblast function, including areas of maturation and regulation of matrix mineralization. In addition to elucidating factors important to cementum development, there is potential for these findings to be extended to the creation of favorable conditions for cementum regeneration.

Acknowledgments. The authors thank the University of Washington Department of Periodontics for their support and Drs. Fernanda Boabaid, Sunao Sato, and Sahba Fatherazi for their assistance. Special thanks are extended to Andrew Fribley for his important role in this work. Thanks also go to Dr. Brian Leroux for his advice on statistical analysis. This study was supported by NIH/NIDCR grant DE15109 and funding from Nestlé Purina PetCare Research.

\section{References}

1. Nociti FH Jr, Berry JE, Foster BL, Gurley KA, Kingsley DM, Takata T, Miyauchi M, Somerman MJ (2002) Cementum: a phosphate-sensitive tissue. J Dent Res 81: 817-821

2. Ho AM, Johnson MD, Kingsley DM (2000) Role of the mouse ank gene in control of tissue calcification and arthritis. Science 289:265-270

3. Sweet HO, Green MC (1981) Progressive ankylosis, a new skeletal mutation in the mouse. J Hered 72:87-93

4. Hakim FT, Cranley R, Brown KS, Eanes ED, Harne L, Oppenheim JJ (1984) Hereditary joint disorder in progressive ankylosis (ank/ank) mice. I. Association of calcium hydroxyapatite deposition with inflammatory arthropathy. Arthritis Rheum 27:1411-1420

5. Sakamoto M, Hosoda Y, Kojimahara K, Yamazaki T, Yoshimura Y (1994) Arthritis and ankylosis in twy mice with hereditary multiple osteochondral lesions: with special reference to calcium deposition. Pathol Int 44:420 427

6. Okawa A, Nakamura I, Goto S, Moriya H, Nakamura Y, Ikegawa S (1998) Mutation in Npps in a mouse model of ossification of the posterior longitudinal ligament of the spine. Nat Genet 19:271-273

7. Hessle L, Johnson KA, Anderson HC, Narisawa S, Sali A, Goding JW, Terkeltaub R, Millan JL (2002) Tissue-nonspecific alkaline phosphatase and plasma cell membrane glycoprotein-1 are central antagonistic regulators of bone mineralization. Proc Natl Acad Sci USA 99:9445-9449

8. Whyte MP (2002) Hypophosphatasia: nature's window to alkaline phosphatase in man. In: Bilezikian JP, Raisz LG, Rodan G. (eds), Principles of bone biology. Academic Press, San Diego, pp 1229-1248

9. Whyte MP (1994) Hypophosphatasia and the role of alkaline phosphatase in skeletal mineralization. Endocr Rev 15:439-461

10. Tesch W, Vandenbos T, Roschgr P, Fratzl-Zelman N, Klaushofer K, Beertsen W, Fratzl P (2003) Orientation of mineral crystallites and mineral density during skeletal development in mice deficient in tissue nonspecific alkaline phosphatase. J Bone Miner Res 18:117-125
11. Girschick HJ, Seyberth HW, Huppertz HI (1999) Treatment of childhood hypophosphatasia with nonsteroidal antiinflammatory drugs. Bone 25:603-607

12. Beertsen W, Van den Bos T, Everts V (1999) Root development in mice lacking functional tissue non-specific alkaline phosphatase gene: inhibition of acellular cementum formation. J Dent Res 78:1221-1229

13. Henthorn PS, Raducha M, Fedde KN, Lafferty MA, Whyte MP (1992) Different missense mutations at the tissue-nonspecific alkaline phosphatase gene locus in autosomal recessively inherited forms of mild and severe hypophosphatasia. Proc Natl Acad Sci USA 89:9924-9928

14. Beck GR Jr, Knecht N (2003) Osteopontin regulation by inorganic phosphate is ERK1/2-, protein kinase C-, and proteasome-dependent. J Biol Chem 278:41921-41929

15. Harmey D, Hessle L, Narisawa S, Johnson KA, Terkeltaub R, Millan JL (2004) Concerted regulation of inorganic pyrophosphate and osteopontin by akp2, enpp1, and ank: an integrated model of the pathogenesis of mineralization disorders. Am J Pathol 164:1199-1209

16. D’Errico JA, Berry JE, Ouyang H, Strayhorn CL, Windle JJ, Somerman MJ (2000) Employing a transgenic animal model to obtain cementoblasts in vitro. J Periodontol 71:63-72

17. Meleti Z, Shapiro IM, Adams CS (2000) Inorganic phosphate induces apoptosis of osteoblast-like cells in culture. Bone 27:359-366

18. Beck GR Jr, Moran E, Knecht N (2003) Inorganic phosphate regulates multiple genes during osteoblast differentiation, including Nrf2. Exp Cell Res 288:288-300

19. Wang D, Christensen K, Chawla K, Xiao G, Krebsbach PH, Franceschi RT (1999) Isolation and characterization of MC3T3-E1 preosteoblast subclones with distinct in vitro and in vivo differentiation/mineralization potential. J Bone Miner Res 14:893-903

20. Fisher LW, Fedarko NS (2003) Six genes expressed in bones and teeth encode the current members of the SIBLING family of proteins. Connect Tissue Res 44(suppl 1):33-40

21. Qin C, Baba O, Butler WT (2004) Post-translational modifications of sibling proteins and their roles in osteogenesis and dentinogenesis. Crit Rev Oral Biol Med 15:126-136

22. Huq NL, Cross KJ, Ung M, Reynolds EC (2005) A review of protein structure and gene organisation for proteins associated with mineralised tissue and calcium phosphate stabilisation encoded on human chromosome 4. Arch Oral Biol 50:599-609

23. Jain A, Karadag A, Fohr B, Fisher LW, Fedarko NS (2002) Three SIBLINGs (small integrin-binding ligand, N-linked glycoproteins) enhance factor H's cofactor activity enabling MCP-like cellular evasion of complement-mediated attack. J Biol Chem 277:13700-13708

24. Fedarko NS, Jain A, Karadag A, Fisher LW (2004) Three small integrin binding ligand $\mathrm{N}$-linked glycoproteins (SIBLINGs) bind and activate specific matrix metalloproteinases. FASEB J 18:734-736

25. Kaartinen MT, Sun W, Kaipatur N, McKee MD (2005) Transglutaminase crosslinking of SIBLING proteins in teeth. J Dent Res 84:607-612

26. Boskey AL, Maresca M, Ullrich W, Doty SB, Butler WT, Prince CW (1993) Osteopontin-hydroxyapatite interactions in vitro: inhibition of hydroxyapatite formation and growth in a gelatin-gel. Bone Miner 22:147-159

27. Harris NL, Rattray KR, Tye CE, Underhill TM, Somerman MJ, D'Errico JA, Chambers AF, Hunter GK, Goldberg HA (2000) Functional analysis of bone sialoprotein: identification of the hydroxyapatite-nucleating and cell-binding domains by recombinant peptide expression and site-directed mutagenesis. Bone 27:795-802

28. He G, Dahl T, Veis A, George A (2003) Dentin matrix protein 1 initiates hydroxyapatite formation in vitro. Connect Tissue Res 44(suppl 1):240-245

29. Baba O, Qin C, Brunn JC, Wygant JN, McIntyre BW, Butler WT (2004) Colocalization of dentin matrix protein 1 
and dentin sialoprotein at late stages of rat molar development. Matrix Biol 23:371-379

30. Ye L, MacDougall M, Zhang S, Xie Y, Zhang J, Li Z, Lu Y, Mishina Y, Feng JQ (2004) Deletion of dentin matrix protein-1 leads to a partial failure of maturation of predentin into dentin, hypomineralization, and expanded cavities of pulp and root canal during postnatal tooth development. J Biol Chem 279:19141-19148

31. Ye L, Mishina Y, Chen D, Huang H, Dallas SL, Dallas MR, Sivakumar P, Kunieda T, Tsutsui TW, Boskey A, Bonewald LF, Feng JQ (2005) Dmp1-deficient mice display severe defects in cartilage formation responsible for a chondrodysplasia-like phenotype. J Biol Chem 280: 6197-6203

32. Takano Y, Sakai H, Watanabe E, Ideguchi-Ohma N, Jayawardena CK, Arai K, Asawa Y, Nakano Y, Shuda Y, Sakamoto Y, Terashima T (2003) Possible role of dentin matrix in region-specific deposition of cellular and acellular extrinsic fibre cementum. J Electron Microsc (Tokyo) 52:573-580

33. Johnson KA, Hessle L, Vaingankar S, Wennberg C, Mauro S, Narisawa S, Goding JW, Sano K, Millan JL, Terkeltaub R (2000) Osteoblast tissue-nonspecific alkaline phosphatase antagonizes and regulates PC-1. Am J Physiol Regul Integr Comp Physiol 279:R1365R 1377

34. Johnson K, Goding J, Etten D Van, Sali A, Hu SI, Farley D, Krug H, Hessle L, Millan JL, Terkeltaub R (2003) Linked deficiencies in extracellular $\mathrm{PP}_{\mathrm{i}}$ and osteopontin mediate pathologic calcification associated with defective PC-1 and ANK expression. J Bone Miner Res 18:994-1004

35. Nielsen LB, Pedersen FS, Pedersen L (2001) Expression of type III sodium-dependent phosphate transporters/retroviral receptors mRNAs during osteoblast differentiation. Bone 28:160-166

36. Murshed M, Harmey D, Millan JL, McKee MD, Karsenty G (2005) Unique coexpression in osteoblasts of broadly expressed genes accounts for the spatial restriction of ECM mineralization to bone. Genes Dev 19:1093-1104

37. Zhao M, Berry JE, Somerman MJ (2003) Bone morphogenetic protein-2 inhibits differentiation and mineralization of cementoblasts in vitro. J Dent Res 82:23-27

38. Goziotis A, Sukhu B, Torontali M, Dowhaniuk M, Tenenbaum HC (1995) Effects of bisphosphonates APD and HEBP on bone metabolism in vitro. Bone 16:317S$327 \mathrm{~S}$

39. D'Aoust P, McCulloch CA, Tenenbaum HC, Lekic PC (2000) Etidronate (HEBP) promotes osteoblast differentiation and wound closure in rat calvaria. Cell Tissue Res $302: 353-363$
40. Chun YH, Foster BL, Lukasavage PA, Berry JE, Zhao M, Tenenbaum H, Somerman M (2005) Bisphosphonate modulates cementoblast behavior in vitro. J Periodontol 76:1890-1900

41. Terkeltaub RA (2001) Inorganic pyrophosphate generation and disposition in pathophysiology. Am J Physiol Cell Physiol 281:C1-C11

42. Beck GR Jr, Zerler B, Moran E (2000) Phosphate is a specific signal for induction of osteopontin gene expression. Proc Natl Acad Sci USA 97:8352-8357

43. Beck GR Jr (2003) Inorganic phosphate as a signaling molecule in osteoblast differentiation. $\mathbf{J}$ Cell Biochem 90:234-243

44. Zhao M, Xiao G, Berry JE, Franceschi RT, Reddi A, Somerman MJ (2002) Bone morphogenetic protein 2 induces dental follicle cells to differentiate toward a cementoblast/osteoblast phenotype. J Bone Miner Res 18:1441-1451

45. Mansfield K, Rajpurohit R, Shapiro IM (1999) Extracellular phosphate ions cause apoptosis of terminally differentiated epiphyseal chondrocytes. J Cell Physiol 179: 276-286

46. Bosshardt DD (2005) Are cementoblasts a subpopulation of osteoblasts or a unique phenotype? J Dent Res 84: 390-406

47. MacNeil RL, D'Errico JA, Ouyang H, Berry J, Strayhorn C Somerman MJ (1998) Isolation of murine cementoblasts: unique cells or uniquely-positioned osteoblasts? Eur J Oral Sci 106(suppl 1):350-356

48. Boabaid F, Berry JE, Koh AJ, Somerman MJ, McCauley LK (2004) The role of parathyroid hormone-related protein in the regulation of osteoclastogenesis by cementoblasts. J Periodontol 75:1247-1254

49. Nociti FH Jr, Foster BL, Barros SP, Darveau RP, Somerman MJ (2004) Cementoblast gene expression is regulated by Porphyromonas gingivalis lipopolysaccharide partially via toll-like receptor-4/MD-2. J Dent Res 83:602-607

50. Narayanan K, Ramachandran A, Hao J, He G, Park KW, Cho M, George A (2003) Dual functional roles of dentin matrix protein 1 . Implications in biomineralization and gene transcription by activation of intracellular $\mathrm{Ca}^{2+}$ store. J Biol Chem 278:17500-17508

51. Mansfield K, Pucci B, Adams CS, Shapiro IM (2003) Induction of apoptosis in skeletal tissues: phosphatemediated chick chondrocyte apoptosis is calcium dependent. Calcif Tissue Int 73:161-172

52. Adams CS, Mansfield K, Perlot RL, Shapiro IM (2001) Matrix regulation of skeletal cell apoptosis. Role of calcium and phosphate ions. J Biol Chem 276:2031620322 